\title{
Prenatal diagnosis of homozygous $\alpha$ thalassaemia by direct DNA analysis of uncultured amniotic fluid cells
}

\author{
VIVIAN CHAN, A GHOSH, T K CHAN, VIVIAN WONG, D TODD
}

\begin{abstract}
Prenatal diagnosis of homozygous $\alpha$ thalassaemia was performed in eight successive patients at risk using DNA from uncultured amniotic fluid cells. The presence of $\alpha$ gene was determined by restriction endonuclease mapping and hybridisation with cloned $\alpha$ and $\beta$ globin probes.

This method is reliable and may be performed at 16 weeks of gestation.
\end{abstract}

\section{Introduction}

Homozygous $\alpha$ thalassaemia which presents as haemoglobin Barts hydrops fetalis arises from the deletion of all four $\alpha$ globin structural genes. ${ }^{1-3}$ This condition is more common in South East Asia owing to the higher prevalence of $\alpha$ thalassaemia $1(--/ \alpha \alpha)$ in this area than in the Mediterranean region and Africa. ${ }^{4}$ The affected fetus usually dies in utero between 23 and 38 weeks of pregnancy or soon after birth. ${ }^{6}$ Despite the invariably fatal consequences of the homozygous state early diagnosis is still desirable, since these pregnancies are often complicated by pre-eclampsia, with significant maternal morbidity and mortality. " Wong et al first employed liquid hybridisation of DNA from cultured amniotic fluid cells for prenatal diagnosis of homozygous $\alpha$ thalassaemia. ${ }^{8} \mathrm{With}$ the development of restriction endonucleases and Southern blotting, direct DNA analysis was possible. ${ }^{9}$ In addition, if amniocentesis is

University Department of Medicine, Queen Mary Hospital, Hong Kong

VIVIAN CHAN, PHD, DIC, reader

T K CHAN, MD, FRCP, professor

D TODD, MD, FRCP, professor

University Department of Obstetrics, Queen Mary Hospital, Hong Kong

A GHOSH, MB, MRCOG, lecturer

VIVIAN WONG, MRCP, MRCOG, senior lecturer

Correspondence to: Dr Vivian Chan. performed at 16 weeks of gestation enough DNA may be isolated from amniotic fluid cells without the need for culture. ${ }^{10}$

We report our preliminary experience of prenatal diagnosis for homozygous $\alpha$ thalassaemia using direct DNA analysis.

\section{Subjects, materials, and methods}

Over two months eight pregnant Chinese women with a history of delivery of an infant with haemoglobin Barts hydrops fetalis requested prenatal diagnosis. All except one were in the second trimester (16-23 weeks); the remaining patient (case 3 ; see table) presented in the 32 nd week with mild hypertension. Amniocentesis was performed under ultrasound guidance and $18-26 \mathrm{ml}$ amniotic fluid obtained. DNA was extracted from the cells as described ${ }^{11}$ and digested with the restriction enzyme Eco RI or Bgl II. After electrophoresis and Southern transfer of the DNA fragments the filter was hybridised overnight with equal amounts of ${ }^{32} \mathrm{P}$ labelled $a$ and $\beta$ globin probes prepared by nick translation of the cloned DNA using the modified method of Rigby et al. ${ }^{12}$ The $\beta$ globin probe had previously been restricted with Bam HI and Eco RI. The hybridised filter was then washed under stringent conditions and autoradiographed from two to four days. On each occasion DNA from a normal person was digested and hybridised as control.

\section{Results}

GENE MAP

The number of amniotic fluid cells obtained by amniocentesis varied with gestational age (table). A total of $4.06 \times 10^{6}$ cells were obtained from a 32 week fetus, yielding $29 \mu \mathrm{g}$ DNA-enough for six enzyme digestions. Even the minimum number obtained from amniocentesis at 16 weeks $\left(0.29 \times 10^{6}\right.$ cells $)$, however, gave sufficient DNA for a single enzyme digestion.

The figure shows the autoradiograph of the $\alpha$ and $\beta$ globin DNA map. Non-thalassaemic human cellular DNA when digested with Eco RI showed a 23 kilobase (kb) $\alpha$ fragment and a $5.5 \mathrm{~kb} \mathrm{5}-\beta$ fragment. Digestion with Bgl II yielded two normal $\alpha$ gene fragments, 12.5 and $7.0 \mathrm{~kb}$ long, and a single $5.3 \mathrm{~kb} \beta$ gene fragment. The radioactive intensities of the $\alpha$ and $\beta$ fragments were similar. Two patients (cases 3 and 4) had no $\alpha$ gene but a normal $\beta$ gene. This is diagnostic of homozygous $\alpha$ thalassaemia and was confirmed at delivery when cellulose acetate electrophoresis of cord blood haemolysates showed the 
Data on eight successive patients for prenatal diagnosis

\begin{tabular}{|c|c|c|c|c|c|c|c|}
\hline \multirow{2}{*}{ Case No } & \multirow{2}{*}{$\begin{array}{l}\text { Gestational age } \\
\text { at diagnosis } \\
\text { (weeks) }\end{array}$} & \multirow{2}{*}{$\begin{array}{c}\text { Amniotic } \\
\text { fluid } \\
(\mathrm{ml})\end{array}$} & \multirow{2}{*}{$\begin{array}{l}\text { Total amniotic } \\
\text { fluid cells } \\
\left(\times 10^{6}\right)\end{array}$} & \multirow{2}{*}{$\begin{array}{c}\text { Total DNA } \\
\text { content } \\
(\mu \mathrm{g})\end{array}$} & \multicolumn{2}{|c|}{ Gene map } & \multirow{2}{*}{ Outcome } \\
\hline & & & & & $\alpha$ & $\beta$ & \\
\hline $\begin{array}{l}1 \\
2 \\
3 \\
4 \\
5 \\
6 \\
7 \\
8\end{array}$ & $\begin{array}{l}21 \\
21 \\
32 \\
23 \\
20 \\
18 \\
16 \\
18\end{array}$ & $\begin{array}{l}18 \\
24 \\
24 \\
25 \\
24 \\
24 \\
26 \\
26\end{array}$ & $\begin{array}{l}1.80 \\
0.41 \\
4.06 \\
1.95 \\
1.44 \\
0.50 \\
0.29 \\
0.62\end{array}$ & $\begin{array}{l}17 \cdot 5 \\
\text { ND } \\
29 \cdot 0 \\
14 \cdot 5 \\
10 \cdot 5 \\
\text { ND } \\
\text { ND } \\
\text { ND }\end{array}$ & $\begin{array}{l}\text { Present } \\
\text { Unsuccess } \\
\text { Absent } \\
\text { Absent } \\
\text { Present } \\
\text { Present } \\
\text { Present } \\
\text { Present }\end{array}$ & $\begin{array}{l}\text { Present } \\
\text { sful } \\
\text { Present } \\
\text { Present } \\
\text { Present } \\
\text { Present } \\
\text { Present } \\
\text { Present }\end{array}$ & $\begin{array}{l}34 \text { weeks; Normal* } \\
23 \text { weeks; induced abortion; Hb Barts } 82.5 \% \\
34 \text { weeks; induced labour; Hb Barts } 86.6 \% \\
25 \text { weeks; induced abortion; Hb Barts } 81.5 \% \\
26 \text { weeks; normal } \\
24 \text { weeks; normal } \\
29 \text { weeks; normal } \\
20 \text { weeks; normal }\end{array}$ \\
\hline
\end{tabular}

ND $=$ Not determined.

* Normal indicates no hydropic changes on ultrasound.

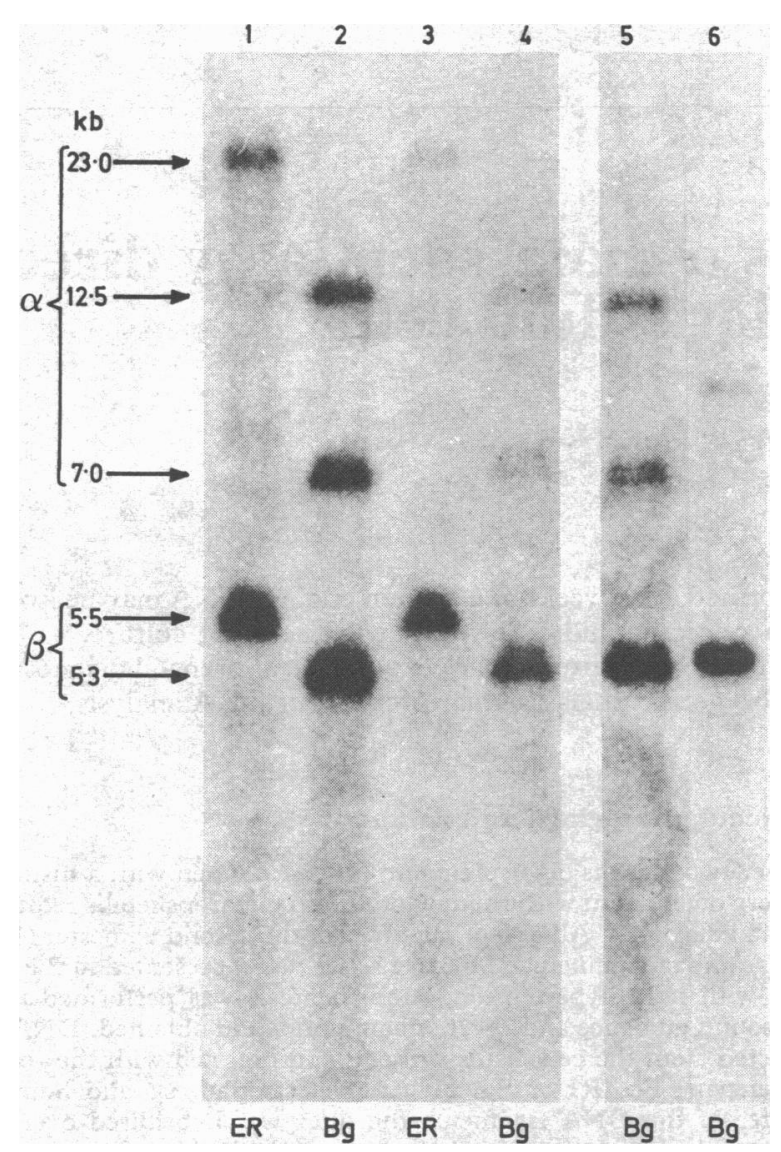

Autoradiograph of filter containing human DNA digested with either Eco RI (ER) or Bgl II (Bg) and hybridised with equal amounts of ${ }^{32} \mathrm{P}$ labelled $\alpha$ and $\beta$ globin DNA. Arrows indicate size of gene fragments in kilobases $(\mathrm{kb}) . \alpha$ Gene fragments are $23 \cdot 0,12 \cdot 5$, and $7 \cdot 0 \mathrm{~kb} ; \beta$ fragments are $5 \cdot 5$ and $5 \cdot 3 \mathrm{~kb}$.

Lanes 1,2 show samples from non-thalassaemic control. Lanes $3,4,5$ show samples from fetuses with $\alpha$ thalassaemia trait. Lane 6 shows sample from fetus with homozygous $\alpha$ thalassaemia.

presence of haemoglobin Barts $(86.6 \%$ and $81.5 \%$ respectively) and haemoglobin Portland $(13.4 \%$ and $18.5 \%$ respectively). Five other patients (cases $1,5,6,7$, and 8 ) showed $\alpha$ and $\beta$ globin genes in the normal position, but the radioactive intensity of the $\alpha$ fragments was less than of the $\beta$ fragment, compatible with the diagnosis of $\alpha$ thalassaemia $1(--/ \alpha \alpha)$. In case 2 we failed to achieve complete restriction digestion with Eco RI and no distinguishable gene pattern was observed. All the parents showed the characteristic gene map pattern of $\alpha$ thalassaemia 1 .

\section{ULTRASOUND FINDINGS}

None of the fetuses studied showed abnormalities at the time of amniocentesis. When case 2 was recalled for a possible second amniocentesis at 23 weeks ultrasound showed evidence of ascites in the fetus; the mother, who had had two previous pregnancies complicated by hydrops fetalis, requested termination. Subsequent cord blood studies showed that this fetus also was affected with homozygous $\alpha$ thalassaemia. None of the other fetuses showed any abnormality at subsequent follow up by fortnightly ultrasonography up to the time of this report (table).

\section{Discussion}

Haemoglobin Barts hydrops fetalis is common in South East Asia ${ }^{13}$ owing to the high prevalence (3-5\%) of $\alpha$ thalassaemia 1 in the population. ${ }^{14}$ Thus parents with a history of haemoglobin Barts hydrops fetalis should be counselled about prenatal diagnosis. In addition, couples of South East Asian origin who have microcytic hypochromic red cells, a normal haemoglobin $\mathrm{A}_{2}$ concentration, and no iron deficiency should be referred for investigation, and if diagnosed as $\alpha$ thalassaemia 1 they should also be counselled.

Amniocentesis carries a very low risk to both the mother and fetus. ${ }^{15}$ The enhanced sensitivity of direct DNA analysis avoids the need for amniotic fluid cell culture. We found that it was possible to obtain a gene map with DNA from $0.29 \times 10^{6}$ cells obtained by amniocentesis at 16 weeks of gestation. This was probably due to the higher specific activity and affinity of the cloned $\alpha$ and $\beta$ globin probes used, whereas other workers have used DNA synthesised with reverse transcriptase from globin mRNA. ${ }^{6}$ ? Results can be obtained within nine to 10 days, so that if amniocentesis is attempted at 16 weeks, termination, if indicated, may be done well before 24 weeks. In this study we attempted prenatal diagnosis even in a third trimester pregnancy. This is not usual, but the patient was already in advanced gestation when the laboratory procedure for DNA analysis was established. She developed mild hypertension and hydramnios and we considered that prenatal diagnosis even at that late stage was desirable, since it would influence her obstetric management. Chorionic villi may be used as a source of fetal DNA and biopsy done between eight and 10 weeks of gestation, ${ }^{16}$ thus allowing earlier prenatal diagnosis. While there are considerable advantages of diagnosis in the first trimester, further experience from a larger biopsy series is required to assess the safety of the procedure compared with the risk of spontaneous abortion during early pregnancy.

The limited amount of DNA extractable from amniotic fluid cells makes the choice of restriction enzyme important. Complete digestion with Eco RI and the subsequent Southern transfer of the larger $\alpha$ fragment are difficult, so that $\mathrm{Bgl}$ II is preferable. The additional use of $\beta$ DNA probe in the hybridisation served as an internal control to indicate efficient extraction of DNA from the amniotic fluid cells.

Prenatal diagnosis of homozygous $\alpha$ thalassaemia is still not available in most parts of South East Asia, and for these regions ultrasonography may be used as an alternative to detect hydrops fetalis. ${ }^{17}$ Although it is sometimes possible to detect ascites and hydropic changes before the 24th week, however, these are not always evident: in our case 3 no ultrasound abnormalities were observed even at 34 weeks. Since amniotic fluid cells may be frozen and shipped to laboratories, amniocentesis and prenatal diagnosis should be offered to couples at risk. 
We thank Professor Y W Kan for advice and encouragement; Dr B Forget and $\mathrm{Dr} \mathrm{T}$ Maniatis for $\alpha$ and $\beta$ globin probes; $\mathrm{S} \mathrm{H}$ Ho Foundation Ltd, Wideland Foundation Ltd, and Wu Chung Travelling Fellowship for financial support; and Messrs A Wong and C S Kwan for skilful technical work.

\section{References}

1 Ottolenghi S, Lanyon WG, Paul J, et al. The severe form of $\alpha$ thalassaemia is caused by a haemoglobin gene deletion. Nature 1974 ;251:389-91.

${ }^{2}$ Taylor JM, Dozy A, Kan YW, et al. Genetic lesion in homozygous $\alpha$ thalassaemia (hydrops fetalis). Nature 1974;251:392-4.

${ }^{3}$ Pressley L, Higgs DR, Clegg JB, Weatherall DJ. Gene deletions in $\alpha$ thalassemia prove that the 5 ' $\zeta$ locus is functional. Proc Natl Acad Sci USA 1980;77:3586-9.

4 Kattamis C, Metaxotou-Mavromati A, Tsiarta E, et al. Haemoglobin Barts hydrops syndrome in Greece. $B r$ Med $\mathcal{F} 1980 ; 281: 268-70$.

${ }^{5}$ Dozy AM, Kan YW, Embury SH, et al. $\alpha$-Globin gene organisation in blacks precludes the severe form of $\alpha$-thalassaemia. Nature $1979 ; 280$ : 605-7.

${ }^{6}$ Lie-Injo LE. Alpha-chain thalassemia and hydrops fetalis in Malaya : report of 5 cases. Blood 1962;20:581-90.
' Wasi P, Na-Nakorn S, Pootrakul S, et al. Alpha- and beta-thalassemia in Thailand. Ann NY Acad Sci 1969;165:60-82.

8 Wong V, Ma HK, Todd D, et al. Diagnosis of homozygous $\alpha$-thalassemia in cultured amniotic-fluid fibroblasts. $N$ Engl f Med 1978;298:669-70.

9 Dozy AM, Forman EN, Abuelo DN, et al. Prenatal diagnosis of homozygous $\alpha$-thalassemia. $\mathcal{F} A M A$ 1979;241:1610-2.

10 Kan YW, Trecartin RF, Dozy AM. Prenatal diagnosis of hemoglobinopathies. Ann NY Acad Sci 1980;344:141-50.

$1 \mathrm{Kan}$ YW, Dozy AM. Antenatal diagnosis of sickle-cell anaemia by DNA analysis of amniotic-fluid cells. Lancet 1978;ii:910-2.

12 Rigby PWJ, Dieckmann M, Rhodes C, Berg P. Labelling deoxyribonucleic acid to high specific activity in vitro by nick translation with DNA polymerase I. $\mathcal{f}$ Mol Biol 1977;113:237-51.

13 Wasi P, Na-Nakorn S, Pootrakul S. The $\alpha$ thalassaemias. Clin Haematol $1974 ; 3: 383-411$.

14 Todd D, Lai MCS, Braga CA, Soo HN. Alpha-thalassaemia in Chinese: cord blood studies. Br $\mathcal{F}$ Haematol 1969;16:551-6.

15 MRC Working Party on Amniocentesis. An assessment of the hazards on amniocentesis. Br $\mathcal{F}$ Obstet Gynaecol 1978;85, suppl 2.

16 Williamson R, Eskdale J, Coleman DV, et al. Direct gene analysis of chorionic villi: a possible technique for first-trimester antenatal diagnosis of haemoglobinopathies. Lancet 1981 ;ii:1125-9.

17 Ghosh A, Woo J, Liang ST, et al. Ultrasonic diagnosis of hydrops fetalis in the early second trimester. Aust NZ F Obstet Gynaecol 1983;23:108-9.

(Accepted 8 February 1984)

\title{
Fetal circulation during epidural analgesia for caesarean section
}

\author{
A LINDBLAD, K MARŠÁL， E VERNERSSON, H RENCK
}

\begin{abstract}
Fetal blood flow was examined during epidural analgesia in six women with uncomplicated pregnancies undergoing elective caesarean section. A non-invasive, ultrasonic technique was used to measure blood flow in the fetal descending aorta and intra-abdominal part of the umbilical vein before induction of analgesia with etidocaine and bupivacaine and 15 and 30 minutes afterwards. No appreciable change in fetal blood flow was observed.
\end{abstract}

\section{Introduction}

Lumbar epidural analgesia is being increasingly used for elective caesarean section. Among its advantages over general anaesthesia are the lack of drug induced respiratory depression of the newborn and the better preserved placental blood flow. ${ }^{1}$ Until now the fetal heart rate has been the only fetal circulatory variable to be controlled under obstetric analgesia. Recently, a non-invasive method of measuring fetal blood flow became available. ${ }^{2}$ We used this new method to evaluate possible effects of epidural analgesia on fetal circulation.

\footnotetext{
Department of Obstetrics and Gynaecology, General Hospital, S-214 01 Malmö, Sweden

A LINDBLAD, MD, senior registrar

K MARŚÁL, MD, senior lecturer

Department of Anaesthesia, General Hospital, Malmö

E VERNERSSON, MD, senior registrar

H RENCK, MD, professor

Correspondence to: Dr K Maršál.
}

\section{Patients and methods}

Fetal blood flow was examined in six women with uncomplicated pregnancies who were to be delivered by elective caesarean section. The indications for caesarean section were cephalopelvic disproportion in five cases and the age of the mother in one (she was a 42 year old primigravida). All of the women gave their informed consent.

The blood flow in the fetal descending aorta and the intra-abdominal part of the umbilical vein was examined with a $2 \mathrm{MHz}$ pulsed Doppler technique combined with real time B mode ultrasonography. ${ }^{2}$ The mean blood flow was calculated and the waveform of the maximum blood velocity analysed. The waveform was characterised by the pulsatility index (= (peak velocity -minimum velocity)/ mean velocity). ${ }^{3}$ The measurements were performed with the pregnant woman tilted slightly to the left $\left(15^{\circ}\right)$ to avoid hypotension. Fetal heart rate and the maternal pulse rate and blood pressure were also measured. Fetal blood flow was recorded before the induction of epidural analgesia and 15 and 30 minutes thereafter.

After preloading with 0.51 of a balanced electrolyte solution analgesia was induced at the L3-4 interspace using $10 \mathrm{ml}$ etidocaine $1.5 \%$ and $10-12 \mathrm{ml}$ bupivacaine $0.5 \%$ both containing adrenaline $(5 \mu \mathrm{g} / \mathrm{ml})$. Cutaneous analgesia up to the level of $\mathrm{T} 7$ and $\mathrm{T} 5$ ensued after 15 and 30 minutes, respectively.

The women were then delivered by caesarean section. The infants had a mean gestational age of 38.2 (SEM 0.3) weeks, a mean birth weight of 3388 (194) $\mathrm{g}$, a mean umbilical arterial $\mathrm{pH}$ of $7.22(0.02)$, and a mean umbilical venous $\mathrm{pH}$ of $7.28(0.02)$. The one minute Apgar score was $\geqslant 8$ in all of them.

\section{Results}

The table gives the mean values of the maternal and fetal circulatory variables. In no instance was the maternal systolic blood pressure lower than $100 \mathrm{~mm} \mathrm{Hg}$. The mean blood velocity and the diameters of the fetal aorta and umbilical vein were within the normal range before analgesia in all six fetuses and did not change during the study period. The figure shows the fetal aortic and umbilical blood flows; no appreciable change in fetal blood flow was observed. 